\section{Research Article}

(C) 2022 Faozi et al. This is an open access article licensed under the Creative Commons Attribution-NonCommercial 4.o International License (https://creativecommons.org/licenses/by-nc/4.o/)

\title{
Bank Compliance Factors in Implementing Regulation Provisions on Bank Performance in Indonesia
}

\author{
Safik Faozi \\ Bambang Sudiyatno \\ Elen Puspitasari \\ Rr Tjahjaning Poerwati \\ Universitas Stikubank (UNISBANK) Semarang, \\ Jl. Tri Lomba Juang, Mugassari, Kec. Semarang Sel., \\ Kota Semarang, Jawa Tengah 50241, Indonesia
}

DOI: https://doi.org/10.36941/ajis-2022-0028

\begin{abstract}
This study aims to examine the effect of legal compliance on the health of commercial banks and Islamic banks in Indonesia, to the extent that compliance with the provisions and standards set by Bank Indonesia has an impact on improving bank performance. This study uses micro banking data listed on the Indonesia Stock Exchange (IDX) for the period 2015-2019. The data used is panel data that is tested in the relationship between measures of bank health legal compliance with indicators of capital, asset quality, management, earnings, and market risk sensitivity (CAMELS). The results of this study indicate that compliance with earnings and compliance with market risk sensitivity has a negative effect on bank performance, while compliance with liquidity has no effect on bank performance. Furthermore, three control variables used in this study, namely capital, asset quality, and corporate governance, were able to produce results as predicted.
\end{abstract}

Keywords: Asset quality, Capital, Earnings, Liquidity, Management, Market risk sensitivity

\section{Introduction}

The banking industry is a group of industrial sectors that plays an important role in increasing economic activity in Indonesia. It can even be said to be a life support industry for the national economy through financing in various sectors of business activity. The banking system in Indonesia is regulated under UU No. 7 of 1992 (amended by UU No. 10 of 1998), while banking regulations are stipulated in the form of Bank Indonesia Regulations (PBI). In accordance with the UU, Indonesia banking can groupers according to type: Commercial Bank and Rural Bank, both types of banks carry out conventional and sharia activities internationally. The two types of banks complement each other in financing business activities, not only international between countries in export-import activities but also national ones between regions, and even to remote rural areas.

In accordance with Bank Indonesia Regulation (PBI) number 13/1 / PBI / 211, banks are required 
to assess the soundness of the bank individually using a risk-based bank rating approach, with a coverage of the assessment of factors: risk profile, good corporate governance, earnings, and capital. The provision for banks to assess of bank soundness is intended to create a sound banking structure capable to fulfil the needs of the consumer and supporting sustainable national economic development. A sound banking structure aims to strengthen bank capital to increase the ability of banks to manage business and risk, develop information technology, and increase their business scale to support increased capacity for bank credit growth. Therefore, banks as intermediary institutions in the financial sector have certain features related to the provisions that must be complied with in comparison with companies in other industrial sectors, to remain able to carry out their operations. These regulations must be complied with to maintain the sounder of the bank and do not to cause problems in supporting sustainable economic activity. The provisions and standards that must be obeyed, such as a capital adequacy ratio (CAR) of at least 8 percent, a maximum non-performing loan (NPL) of 5 percent, a net interest margin (NIM) of at least 6 percent, and a loan to deposit ratio (LDR) of 75 - 105 percent. If a bank does not comply with these rules, it will create risks that can harm the bank, and can reduce the soundness of the bank which will result in a decline in the bank's performance. These provisions and standards are made to maintain the health of the bank so that the bank can function properly as an agent of development.

In accordance with Bank Indonesia regulation Number 6/10/PBI/2004 dated April 12, 2004, the soundness level of a bank is a quantitative and/or qualitative assessment of numerous characteristics that affect the bank's condition or performance, such as capital (C), asset quality (A), management (M), earnings (E), liquidity (L), and market risk sensitivity (S). The CAMELS analysis is a development of CAMEL before adding the last measurement, namely market risk sensitivity. The original form was CAMEL, after US regulations added a component of market risk sensitivity in late 1997. This change has been followed by many bank supervisors around the world (Grier, 2007). Even though CAMEL has developed into CAMELS, the last compony measure, namely market risk sensitivity, may not apply to all commercial banks (Sujarwo, 2015).

The major responsibility of the bank's compliance function in relation to bank compliance with established regulations and standards is to help senior management in managing compliance risk more efficiently. More specifically, compliance with law, provisions and standards that have been determined by Bank Indonesia as the authority and supervising banking industry activities in Indonesia. As defined by the Basel Committee (Basel II), compliance is the risk of legal or regulatory sanctions, financial loss, or loss of reputation that a bank may suffer due to its failure to comply with all applicable laws, regulations, codes of ethics and standards of good bank practice.

The compliance risk is measured by using performance indicators to improve compliance (Misha, 2016), for example an increase in the number of customer complaints, and payment irregularities that cause bad credit. According to Misha (2016), the compliance function also identifies, records, and assesses compliance risks associated with bank operations, including new products and practices, proposals for the formation of new types of business, customer relationships, and material changes in these relationships which cover areas such as loans, operations, deposits, transfers, etc. The extent to which bank compliance practices in implementing the rules and standards of the Indonesian banking industry can be illustrated in Table 1 below. 
Table 1: Compliance to CAR, NPL and LDR

\begin{tabular}{|c|c|c|c|c|c|}
\hline \multirow{2}{*}{ Bank Name } & \multicolumn{5}{|c|}{ Year } \\
\hline & 2015 & 2016 & 2017 & 2018 & 2019 \\
\hline Bank BNI: & (percent) & (percent) & (percent) & (percent) & (percent) \\
\hline CAR & 17 & 18.3 & 17.5 & $17 \cdot 4$ & 18.6 \\
\hline NPL & 2.7 & 3 & 2.3 & 1.9 & 2.3 \\
\hline NIM & 6.4 & 6.2 & $5 \cdot 5$ & $5 \cdot 3$ & 4.9 \\
\hline LDR & 87.80 & 90.40 & 85.60 & 88.80 & 91.50 \\
\hline Bank AGRIS: & & & & & \\
\hline CAR & 18.12 & 17.17 & 18.64 & 15.63 & 14.01 \\
\hline NPL & 1.75 & $3 \cdot 56$ & 5.45 & 6.44 & 7.02 \\
\hline NIM & 3.24 & 3.43 & 3.17 & 3.42 & 3.42 \\
\hline LDR & 78.84 & 84.54 & 84.46 & 84.68 & 84.46 \\
\hline Bank BCA: & & & & & \\
\hline CAR & 18.7 & 21.9 & 23.1 & 23.4 & 23.8 \\
\hline NPL & 0.7 & 1.3 & 1.5 & 1.4 & 1.3 \\
\hline NIM & 6.7 & 6.8 & 6.2 & 6.1 & 6.2 \\
\hline LDR & 81.10 & 77.10 & 78.20 & 81.60 & 80.50 \\
\hline Bank BRI Syariah: & & & & & \\
\hline CAR & 13.94 & 20.63 & 20.05 & 29.73 & 25.26 \\
\hline NPL & 3.89 & 3.19 & 4.75 & 4.97 & 3.38 \\
\hline NIM & 6.38 & 6.37 & 5.84 & 5.36 & 5.72 \\
\hline LDR & 87.80 & 80.50 & 87.50 & 90.10 & 86.30 \\
\hline Bank Maspion Indonesia: & & & & & \\
\hline CAR & 19.33 & 24.32 & 21.59 & 21.28 & 20.19 \\
\hline NPL & 0.51 & 0.91 & 1.52 & 2.14 & 2.34 \\
\hline NIM & 4.42 & 5.28 & 4.95 & 4.75 & 4.14 \\
\hline LDR & 112.54 & 94.54 & 70.28 & 72.59 & 94.13 \\
\hline
\end{tabular}

Source: Annual Report 2015-2019

As shown in Table 1 above, of the 5 banks drawn randomly, several provisions and standards have been adhered to, such as bank capital (CAR) in accordance with the provisions and standards set by Bank Indonesia. However, there are still some indicators that are not in accordance with the provisions and standards, such as market risk sensitivity (NPL), earnings (NIM), and liquidity (LDR); some banks are still not in accordance with the established provisions and standards.

The bank's non-compliance to fulfil the requirements, regulations and standards can result in a decline in bank health, which can lead to a decline in bank performance. Therefore, bank management must be able to properly manage capital, asset quality, management, earnings, liquidity, and market risk sensitivity (CAMELS), so that the bank is in a healthy condition to carry out its operational activities.

The problem of not being able to meet the provisions and standards of CAMELS is not solely because banks do not comply with these provisions and standards but can be caused by other factors both macro in nature beyond the management's ability, such as the condition of the global economic recession which causes economic activity to decline.

Bank capital is a very important element in CAMELS, if the bank capital (CAR) is less than $8 \%$, the bank owners must add their capital deposit to reach CAR 8 percent. If it is unable to comply, Bank Indonesia will have to close, because it will only cause banks to experience liquidity problems which will have a wide impact on the national economy. Asset quality shows the quantity of existing and potential credit risk associated with the loan and investment portfolio. Thus, it is important for banks to organize their loan and investment portfolios to reduce credit risk. Management related to corporate governance is aimed at directing bank management in a professional manner based on the principles of transparency, accountability, responsibility, independence, fairness, and equality. Good corporate governance will produce healthy banks in carrying out their operational activities. Earnings is an element that will ensure the continuity of the bank's business activities because the existence of 
earnings shows that banks can pay interest obligations to customers and investors. Liquidity, as an element of ensuring customer confidence in the bank, is important to maintain this trust to reduce excessive withdrawals by customers. The last element is market risk sensitivity, which shows the bank's ability to respond to changes in the market. These changes are related to changes in interest rate and exchange rates. Banks must be able to anticipate possible movements in interest rates and exchange rates so that these changes do not cause major problems for the bank.

Banks use CAMELS as a risk test to manage risk efficiently as an effort to improve bank performance. When a bank experiences signs of performance problems, it requires strategic management decisions to control these problems, because changes in daily, weekly, monthly, and annual business cycles also affect changes in banking performance (Maryam and Bustaman, 2017). Empirical studies related to CAMELS have been conducted previously by Ayanda (2013), Dogan and Yildiz (2013), Abata and Adeolu (2014), Rostami et al (2015), Lucky and Andrew (2015), Rahman et al (2015), and John (2018). Ayanda's research (2013) found that capital and liquidity had no effect on bank performance, while research results from Rahman et al (2015) found a positive effect. Research results from Dogan and Yildiz (2013), found that corporate governance has a negative effect on bank performance, while research from Rostami et al (2015) found a positive effect. Abata and Adeolu (2014), found that asset quality has a negative effect on bank performance, while research from Lucky and Andrew (2015) did not find an effect of asset quality on bank performance. Still from the research of Lucky and Andrew (2015) did not find the effect of market sensitivity on bank performance, but John (2018) found a negative effect of market sensitivity on bank performance.

\section{Literature Review and Hypothesis Development}

\subsection{Basic Concepts}

Capital adequacy, asset quality, management, earnings, liquidity, and sensitivity and abbreviated as CAMELS is an international rating system used by regulatory banking authorities to rate financial institutions. This model determines the evaluation of a bank on the basis of six important dimensions, namely capital, asset quality, management, earnings, liquidity, and market sensitivity. Market risk sensitivity was only added in 1997 (Mehdi, 2018). These components are used to reflect the soundness of operations and compliance with financial institution regulations. Of the six components, each is rated on a scale of 1 (best) to a scale 5 (worst). Determination of this ranking is important to assess a bank that is healthy and unhealthy. Rank 1 is a healthy bank condition, exhibit strong performance and risk management practices, so that the bank can improve its performance. The bank's performance is the capacity to generate sustainable profitability. One of the traditional measures of bank performance is return on assets (ROA). which is the profitability ratio that provides how much profit a company can generate from its assets. This ratio measures how efficient a bank's management is in generating earnings from their economic resources. The main theories that explain banks performance are the market power theory (MPT) and efficiency structure theory (EST). According to $\mathrm{Fu}$ and Heffernan (2009), banking performance is solely determined by market structure. Banks can exercise market power over prices and earnings in a concentrated market or with a significant market share by clearly defining their products and therefore increasing abnormal return. According to this idea, banking performance is governed by the market behavior of agents, which is based on their market share.

The Relative Market Theory (RMT) model developed by Shepherd (1983) plays an important role which states that the banking performance depends on market shares. The large banks can offer a variety of different products, which are able to influence prices and increase revenue. With these assumptions, the individual's market share will determine market power and its imperfections. As a result, product differentiation is critical in allowing large banks to employ market forces to set interest rates. The large banks can realize market power and perform better, so that market share power will increase bank performance. 


\subsection{Hypothesis Development}

Using the CAMELS approach, this study examines bank compliance in Indonesia's banking system.

\subsubsection{Capital}

Capital is an important element in the health of a bank, and which will ensure the bank can carry out its operations. A healthy bank is a bank that has sufficient capital to guarantee that there is no risk of capital shortage, therefore the bank must have sufficient capital. The capital adequacy can be assessed based on different factors, including the level and quality of capital and the overall financial condition of the bank. The banks must comply to meet 8 percent capital adequacy in accordance with the provision and standards set by Bank Indonesia. If the bank is unable to comply with these provisions, the owner of the capital must deposit up to 8 percent in accordance with the provisions. The banks with large capital are more likely to take advantage of market structure conditions and dominate market share to increase revenue.

Several previous studies on bank capital were conducted by Kosmidou et al (2005), Davydenco (2011), Rahman et al (2015), Erdogan and Aksoy (2016), Anarfi (2016), Merin (2016), Kadioglu et al (2017), Anggraini and Prastiwi (2019), Harbi (2019), Golubeva et al (2019), and Sunaryo (2020), who found that capital has a positive effect on bank performance. However, Supriyono and Herdhayinta (2019), and Hasan et al (2020), found a negative effect, while Heffernan and Fu (2010) and Silaban (2017, found no effect of capital on bank performance.

$\mathrm{H}_{1}$ : Capital adequacy has a positive effect on the bank performance.

\subsubsection{Asset Quality}

Asset quality shows the quality of available and potential credit risk associated with the loan portfolio and investment and other assets it owns. Bank management must be able to manage these assets to reduce credit risk, in this case management's ability is tested to identify and manage credit risk. The bank's asset structure determines the conditions and ability of the business and households to repay the loans they have received so that the bank's operational activities can run smoothly. The better the asset quality, the better and smoother the repayment of business and household loans, thus reducing the occurrence of bad loans and an impact on increasing bank income.

Banks have an asset in the form of loans to businesses and individuals, and the interest collected on these investments is a major source of revenue and profit for them. The bank's major risk is that loans will not be repaid. The worse the quality of the loan or asset, the larger the credit risk. Banks must retain more capital to cover the associated credit risk and file bigger provisions to account for potential losses when their asset quality declines. Thus, bank management must be able to manage its asset and investment portfolio properly so that asset quality does not decline.

Asset quality is a major problem during an economic downturn, as many borrowers default on their loans and the number of non-performing loans rises. Banks must always follow robust lending criteria, actively monitor asset quality, and proactively tackle ono-performance loans to limit losses and the impact on their soundness and capacity to lend. Research results related to asset quality have been conducted by Abata and Adeolu (2014) and Kadioglu et al (2017), which found that asset quality has a negative effect on bank performance, while research results from Lucky and Andrew (2015) and Anggraini and Prastiwi (2019) found do not effect of asset quality on bank performance.

$\mathrm{H}_{2}$ : Asset quality has a positive effect on the bank performance.

\subsubsection{Management}

The $3^{\text {rd }}$ component of CAMELS is management assessed by different factors, including: the board of directors' and management's ability to plan for and respond to risks that may arise as a result of 
business uncertainty, as well as the level and quality of oversight and support provided to all bank activities by the board of directors and management. As a result, management is linked to corporate governance, which is a set of rules, policies, and procedures for directing and controlling a business. Corporate governance identifies who has power and accountability, as well as who makes decisions, by describing how corporations are governed and for what purpose. Good corporate governance is implemented by banks to increase bank value and performance as well as to maintain the sustainability of bank operations. Research related to corporate governance was conducted by Rostami et al (2015) and Owiredu and Kwakye (2020), who found that corporate governance had a positive effect on bank performance. However, research results from Dogan and Yildiz (2013) found a negative influence between corporate governance and bank performance, while Ene et al (2016) and Sobhy et al (2017) found no influence of corporate governance on bank performance.

$\mathrm{H}_{3}$ : Corporate governance has a positive effect on the bank performance.

\subsubsection{Earnings}

Profit and earnings are often used interchangeably, but they are different. In this case, what is meant by earnings is bank income, which is the core income derived from interest income. This income is obtained from the difference between loan interest or credit interest and deposit interest. In a financial institution such as a bank, the measure of the difference between credit interest income and interest on deposits relative to total interest income is called the net interest margin (NIM). The banks must pay attention to the net interest margin (NIM) because the net interest margin (NIM) is a ratio used as a benchmark to determine how much the bank's ability to manage all its earning assets to generate higher net income.

Research related to net interest margin conducted by Lartey et al (2013), Silaban (2017), Supriyono and Herdhayinta (2019), and Sunaryo (2020) found that net interest margin has a positive effect on the bank performance. However, the results of research from Hasan et al (2020), did not find the effect of net interest margin on the bank performance.

$\mathrm{H}_{4}$ : The compliance to earnings has a positive effect on the bank performance.

\subsubsection{Liquidity}

Liquidity refers to the ease with which an asset, or security, can be converted into ready cash without affecting its market price. Cash is the most liquid of assets, by having sufficient cash the bank can make payment transactions to meet the obligations that have to be paid. Liquidity is assessed based on the adequacy of sources of liquidity compared to current needs without disrupting bank operations. The liquidity aspect as a measure of bank health is carried out using the loan to deposit ratio (LDR) indicator.

The loan-to-deposit ratio is calculated by dividing a bank's total loans by its total deposits over a given period. Divide a bank's total number of loans by the total amount of deposits for the same period to get the loan to deposit ratio. As a result, the loan-to-deposit ratio speaks to a bank's capacity to satisfy its short-term obligations.

Research on loan to deposit ratio was conducted by Kosmidou et al (2005), Samad (2015), Rahman et al (2015), Erdogan and Aksoy (2016), Anarfi (2016), Anggraini and Prastiwi (2019), and Supriyono and Herdhayinta (2019), found that the loan to deposit ratio has a positive effect on bank performance. However, the result of research from Davydenco (2011), and Harbi (2019), found that the loan to deposit ratio has a negative effect on the bank performance. Other research by Heffernan and $\mathrm{Fu}$ (2010), Ayanda (2013), Golubeva et al (2019), Sunaryo (2020), Hasan (et al (2020), found no effect of the loan to deposit ratio on the bank performance.

$\mathrm{H}_{5}$ : The compliance to liquidity has a positive effect on the bank performance. 


\subsubsection{Sensitivity}

Market risk sensitivity relates to a bank's ability to deal with market fluctuation, the market can become very volatile due to good news or bad news. A sensitive market is vulnerable to uncontrollable fluctuations in prices and interest rates. Many banks try to avoid sensitive markets by fixing interest rates or gradually divulging good and bad news, so that their share prices fluctuate smoothly and consistently. An increase in the interest rate will have a negative impact on the development of bank loans and can even cause bad credit. Therefore, bank management must maintain the quality of loans even in conditions of rising interest rates to reduce credit risk.

The market risk sensitivity can be deducted from the non-performing loan (NPL), which is an indicator of bank health. Non-performing loans (NPL) can have an impact on reducing bank capital, and if left untreated, will have an impact on lending for the next period. Research on non-performing loans conducted by Erdogan and Aksoy (2016), Silaban (2017), Kadioglu et al (2017), John (2018), Supriyono and Herdhayitna (2019), and Golubeva et al (2019), found that non-performing loan has a negative effect on the bank performance. Meanwhile, research results from Rahman et al (2015), Lucky and Andrew (2015), Sunaryo (2020), and hasan et al (2020) found no effect of non-performing loans on the bank performance.

$\mathrm{H}_{6}$ : The compliance to sensitivity has a positive effect on the bank performance.

\section{Research Methodology}

This paper aims to analyse bank compliance with regulations and standards as well as their impact on bank performance in the Indonesian banking industry. The data is taken from the annual report of profit and loss and balance sheet of 30 banks that are still actively listed on the Indonesia Stock Exchange (IDX) for the 2015-2019 period. The sampling method uses purposive sampling, as in Table 2 below.

Table 2: Sample Research Data

\begin{tabular}{|c|l|c|}
\hline No & Sample Criteria & Number of Samples \\
\hline 1 & Population & 35 \\
\hline 2 & Banks that are not listed on the IDX since 2015-2019 & 8 \\
\hline 3 & $\begin{array}{l}\text { Banks that do not provide annual report income statements and balance sheets for } \\
\text { the 2015-2019 period }\end{array}$ & 0 \\
\hline 4 & Financial statements that are not stated in rupiah currency & o \\
\hline & Total Samples & 27 \\
\hline
\end{tabular}

Source: Calculations based on IDX data

This study adopts several modifications to the model and methodology used by Harbi (2019). Data analysis uses multiple regression models and is represented in the following equation.

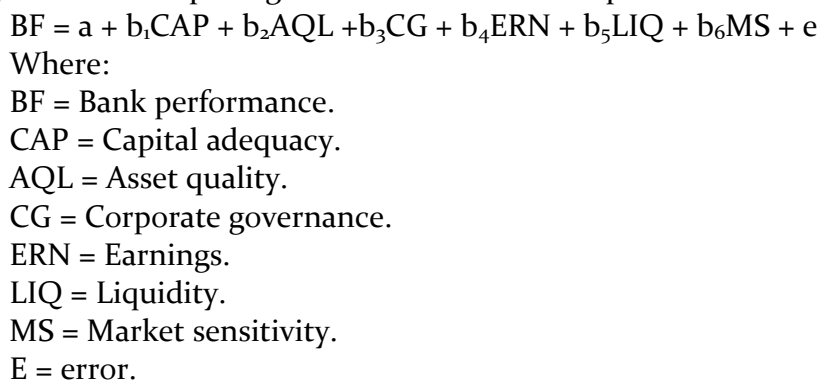




\subsection{Measures of profitability}

The measurement of bank performance in this study is return on assets (ROA), which is defined as profit after tax to total assets and shows the profit earned per rupiah of assets.

\subsection{Determinants of bank profitability}

The factors that determine bank performance are capital, asset quality, management, earnings, liquidity, and market risk sensitivity (CAMELS). Capital, earning, liquidity, and sensitivity as dummy variables, which represent compliance with the provisions of capital, earnings, liquidity, and market risk sensitivity. Meanwhile, asset quality and management are the control variables. These variables as independent variables (Ahsan, 2016) are shown in Table 3 below.

Table 3: Determinants of Bank Profitability

\begin{tabular}{|c|c|c|c|}
\hline Variables & Indicator & Description & \begin{tabular}{|c|}
$\begin{array}{c}\text { Expected } \\
\text { sign }\end{array}$ \\
\end{tabular} \\
\hline $\begin{array}{l}\text { Dependent variables: } \\
\text { Bank performance }\end{array}$ & ROA & Bank's after-tax profits divided by total assets. & \\
\hline $\begin{array}{l}\text { Independent } \\
\text { variables: } \\
\text { Capital } \\
\text { Asset Quality } \\
\text { Management } \\
\text { Earnings } \\
\end{array}$ & $\begin{array}{l}\text { CAR } \\
\text { Total PL } \\
\text { Total Board } \\
\text { of Directors } \\
\text { NIM }\end{array}$ & $\begin{array}{l}\text { Capital divided by risk weighted assets (control variable). } \\
\text { Logarithm of total performance loan (control variable). Total of board directors } \\
\text { (control variable). } \\
\text { Dummy, equal o if the bank has NIM more than } 6 \% \text {, otherwise } 1 .\end{array}$ & $\begin{array}{l}+ \\
+ \\
+ \\
+\end{array}$ \\
\hline Liquidity Sensitivity & $\begin{array}{l}\text { LDR } \\
\text { NPL }\end{array}$ & $\begin{array}{l}\text { Dummy, equal o if the bank has LDR } 75 \%-105 \% \text {, otherwise } 1 . \\
\text { Dummy, equal o if the bank has NPL less than } 5 \% \text {, otherwise } 1 . \\
\text { Bad loans divided by the total amount of outstanding loans in the bank' portfolio. }\end{array}$ & $\begin{array}{l}+ \\
+ \\
+ \\
\end{array}$ \\
\hline
\end{tabular}

\section{Research Discussion}

\subsection{Descriptive Statistics}

Banks that met the sample criteria according to the purposive sampling method were 27 banks, so that the number of $\mathrm{N}$ samples was 135. After being tested for data normality and classical assumptions, the number of $\mathrm{N}$ samples was 119, which were further processed using multiple regression methods. As shown in Table 4, the following are descriptive statistics of $119 \mathrm{~N}$ sample data.

Table 4: Descriptive Statistics

\begin{tabular}{|l|c|c|c|c|c|}
\hline Variables & $\mathrm{N}$ & Minimum & Maximum & Mean & Std. Deviation \\
\hline ERN & 119 & .00 & 1.00 & .7311 & .44527 \\
LIQ & 119 & .00 & 1.00 & .1933 & .39654 \\
MS & 119 & .00 & 1,00 & .0924 & .29087 \\
CAP & 119 & 9.01 & 38.60 & 20.7765 & 5.12815 \\
AQL & 119 & 3.83 & 8.59 & 6.2596 & .96638 \\
CG & 119 & 2.00 & 9.00 & 5.5630 & 2.04872 \\
Valid N (listwise) & 119 & & & & \\
\hline
\end{tabular}

Source: Calculated based on banks data 2015-2019

Based on Table 4, the bank capital (CAP) proxied with the lowest capital adequacy ratio (CAR) is 9.o1 percent and the highest is 38.60 percent with an average of 20.78 percent and a standard deviation of 5.13 percent. Given that there is no bank that does not comply with the provisions and standards of at 
least $8 \%$, this variable cannot be a dummy variable, so it is placed as a control variable. As shown in Table 4, there is no bank with a capital ratio of less than 8 percent. Thus, all banks comply with the provisions and standards set by Bank Indonesia.

Asset quality is proxied by the total performance loan, and for analysis purposes the logarithm of the total performance loan is used, with a logarithm of total loan performance of at least 3.83 and a maximum of 8.59, with an average value of 6.26 and a standard deviation of 0.97 . Even this variable is used as a control variable. One other control variable is corporate governance, which is proxied by the number of boards of directors. As shown in Table 4, the number of boards of directors is at least 2 people and a maximum of 9 people, with an average of 6 people per bank, and a standard deviation of 2.05.

Model testing is done to determine how much the regression model can accurately predict. The test was carried out on the coefficient of determination and the significance test F. The test results of the coefficient of determination and the significance of F are shown in Table 5 and Table 6 below.

Table 5: Coefficient of Determination

\begin{tabular}{|c|c|c|c|c|}
\hline Model & R & R Square & Adjusted R Square & Std. Error of the Estimate \\
\hline 1 & .847 & .718 & .703 & .76051 \\
\hline
\end{tabular}

Source: Calculated based on banks data 2015-2019

As shown in Table 5, the test results of the coefficient of determination show that the adjusted $\mathrm{R}$ square is 0.703 or 70.30 percent. Thus, 70.30 percent of bank performance is influenced by capital, asset quality, management governance, earnings, liquidity, and market risk sensitivity, the rest is determined by other factors.

Table 6: Significance Test F

\begin{tabular}{|l|c|c|c|c|c|}
\hline Model & Sum of Squares & $\mathrm{df}$ & Mean Square & F & Sig \\
\hline 1 Regression & 164.886 & 6 & 27.481 & & \\
Residual & 64.778 & 112 & .578 & 47.514 & .000 \\
Total & 229.664 & 118 & & & \\
\hline
\end{tabular}

Source: Calculated based on banks data 2015-2019

Table 6 shows the results of the F significance test ( $\operatorname{sig}-\mathrm{F}$ ) where the value of $\mathrm{F}=47,514$ with a significance of 0.00 . With the results of the F significance test, it can be concluded that the regression model meets the requirements of goodness of fit, so the regression model is suitable for prediction.

\subsection{Regression Results}

The regression results are shown in Table 7 , as a basis for analysing the effect of capital, asset quality, management, earnings, and market risk sensitivity on bank performance. To test the hypothesis has been done using the t test to determine the level of significance of capital, asset quality, management governance, liquidity, and market risk sensitivity to bank performance. By knowing the significance of $t$ (sig - t) of each of these variables, the variables that have influence and do not affect firm performance, so that we can get a conclusion on the status of each of these independent variables in influencing bank performance. The results of the $t$ significance test (sig - $t$ ) can be seen in Table 7 below. 
Table 7: Significance Test $\mathrm{t}$

\begin{tabular}{|l|c|c|c|c|c|}
\hline \multirow{2}{*}{ Model } & \multicolumn{2}{|c|}{ Unstandardized Coefficients } & Standardized Coefficients & \multirow{2}{*}{$\mathrm{t}$} & \multirow{2}{*}{ sig } \\
\cline { 2 - 5 } & $\mathrm{B}$ & Std. Error & Beta & & \\
\hline 1 (Constant) & -.809 & .657 & -.454 & -8.145 & .000 \\
ERN & -1.442 & .175 & -.074 & -1.419 & .159 \\
LIQ & -.259 & .182 & -.345 & -6.141 & .000 \\
MS & -1.653 & .269 & .172 & 2.862 & .005 \\
CAP & .047 & .016 & .189 & 3.395 & .001 \\
AQL & .272 & 080 & .238 & 4.063 & .000 \\
CG & .162 & 040 & & & \\
\hline
\end{tabular}

Source: Calculated based on banks data 2015-2019

The results of hypothesis testing as shown in Table 7 show that the beta coefficient of capital adequacy is 0.047 with a significance $t=0.005$ less than 5 percent. Thus, capital adequacy has a significant positive effect on bank performance at a significance level of less than 1 percent, so hypothesis 1 is accepted. Asset quality beta coefficient 0.272 with a significance $t=0.001$ less than 5 percent. Thus, asset quality has a significant positive effect on bank performance at a significance level of less than 1 percent, so hypothesis 2 is accepted. The corporate governance beta coefficient is 0.162 with a significance $t=0.000$, less than 5 percent. Thus, corporate governance has a significant positive effect on bank performance at a significance level of less than 1 percent, so hypothesis 3 is accepted. The three variables are control variables and all of them are significant and positive in influencing bank performance. Therefore, capital adequacy, asset quality, and corporate governance can function as control variables in influencing bank performance.

Still as shown in Table 6, the compliance beta coefficient on earnings is -1.442 with a significance $t=0.000$ less than 5 percent. Thus, compliance with earnings has a significant negative effect on bank performance at a significance level of less than 1 percent. However, although statistically compliance with earnings has a significant effect, but in a different direction and not in accordance with the predictions, so that hypothesis 4 is rejected. The beta coefficient of compliance with liquidity is -0.259 with a significance $t=0.159$ greater than 5 percent. Thus, compliance with liquidity has a negative and insignificant effect on bank performance, so hypothesis 5 is rejected. The beta coefficient of compliance with market risk sensitivity is -1.653 with a significance $t=0.000$ less than 5 percent. Thus, compliance with market risk sensitivity has a negative effect on bank performance at a significance level of less than 1 percent, so hypothesis 6 is rejected, because it is not in accordance with what was predicted.

\section{Discussion}

The results of hypothesis testing as shown in Table 7 show that compliance with the earning terms standards has a negative effect on bank performance, the higher the compliance with regulations and earning standards, the lower the bank's performance. Earnings are proxied by the net interest margin, so that the higher the net interest margin, the lower the bank's performance. Banks that comply with the regulations and standards for a net interest margin of more than 6 percent experience a decline in performance. This is probably since most of the banks listed on the Indonesia Stock Exchange (IDX) generate a net interest margin of less than $6 \%$, which has an impact on the decline in bank performance.

The banking industry has a more exclusive market characteristic than other industries. Banks can use market forces and interest rates to increase revenue, with increasing bank income, the bank's performance also increases. However, given their market power, most banks still generate a net interest margin of less than 6 percent. Therefore, the results of this study are not in accordance with 
the concept of market power theory (MPT) and relative market theory (RMT). The market power of the bank is not able to increase the high net interest margin, which results in a decline in bank performance.

The compliance with liquidity has no effect on bank performance. The compliance with liquidity is proxied by the loan to deposit ratio, and legal compliance with liquidity is measured by the provisions and standard loan to deposit ratio of $75-105$ percent. Thus, compliance with liquidity does not affect the increase in bank performance. This condition is in line with the first finding, namely that compliance with earnings has a negative effect on bank performance. Many banks listed on the Indonesia Stock Exchange (IDX) adhere to the terms and conditions for a loan-to-deposit ratio of 75 to 105 percent. This compliance has no impact on bank performance because most banks generate low earnings or net interest margins, which are less than 6 percent.

The compliance with market risk sensitivity has a negative effect on bank performance, the higher the market risk sensitivity, the lower the bank's performance. The compliance with market risk sensitivity is proxied by non-performing loans, and compliance with non-performing loan provisions and standards is a maximum of 5 percent. The non-performing loans of most banks listed on the Indonesia Stock Exchange (IDX) are lower than 5 percent, so they comply with the provisions and standards set by Bank Indonesia. Thus, banks that comply with NPL regulations and standards of less than 5 percent have a negative effect on bank performance. This finding is also in line with previous findings where earnings have a negative impact on bank performance, which means that there may be indications of inefficiency. This is also demonstrated by the fact that many banks listed on the Indonesia Stock Exchange (IDX) generate a net interest margin of less than 6 percent.

\section{Recommendations}

The significant influence of capital adequacy, asset quality and corporate governance as control variables is very important to be developed as a factor that affects bank performance. Further research is encouraged to conduct a comprehensive study on compliance with capital adequacy, asset quality and corporate governance as the main factors in supporting the improvement of bank performance.

\section{Research Limitation}

Although this research has contributed to the development of finance and banking, it also has limitations that need to be addressed. The limitation of this research is only focused on the CAMELS approach as the provisions of bank compliance with regulations as a factor affecting bank performance, while other factors are not considered.

\section{Suggestions for Future Research}

From the limitations of this study, for further research in addition to using the CAMELS approach in analysing the effect of bank compliance on bank performance, researchers can consider the ownership structure and bank size as factors that affect bank performance.

\section{Conclusion}

This paper aims to examine legal compliance with bank soundness standards and regulations in the Indonesian banking industry using the CAMELS approach. The results showed that compliance with earnings regulations and market risk sensitivity had no effect on bank performance. As it has been predicted, capital adequacy, asset quality and corporate governance as control variables have a significant positive effect on bank performance, so that the three variables are able to act as control variables in influencing bank performance. 


\section{References}

Abata., and Adeolu, M. (2014). Asset quality and bank performance: A study of commercial banks in Nigeria. Research Journal of Finance and Accounting, 5(18), 39-44. https://www.iiste.org/Journals/index.php/RJFA/issue/view/1365

Ahsan, M. K. (2016). Measuring financial performance based on CAMEL : A Study on selected Islamic Banks in Bangladesh.p2613, 47-56. https://doi.org/10.18034/abr.v6i1.26

Al-harbi, A. (2019). The determinants of conventional banks profitability in developing and underdeveloped OIC countries. 24(47), 4-28. https://doi.org/10.1108/JEFAS-05-2018-0043

Anarfi, D. (2016). Determinants of bank profitability in Ghana: New evidence. Asian Journal of Finance $\mathcal{E}$ Accounting, 8(2), 194-204. http://www.macrothink.org/journal/index.php/ajfa/article/view/10274 Anggraini, R., and Prastiwi, M. (2020). Determinants of bank profitability: The case of a listed bank on Indonesian Stock Exchange. Jurnal Ekonomi dan Bisnis, 3(2), 274-283. http://ejournal.uin suka.ac.id/febi/ekbis/article/view/1188

Ayanda, A. M. (2013). Determinants of banks' profitability in a developing economy: Evidence from Nigerian banking industry. Interdisciplinary Journal of Contemporary Research in Business, 4(9), 155-181. https://journal-archieves27.webs.com/155-181.pdf

Bank Indonesia. (2004). Peraturan Bank Indonesia Nomor 6/10/PBI/2004 tanggal 12 April 2004 tentang Sistem Penilaian Tingkat Kesehatan Bank Umum. https://peraturan.bpk.go.id/Home/Details/137709/peraturan-bi-no-61opbi2004

Basel Committee on Banking Supervision - Compliance and the compliance function in banks, April 2005. https://www.bis.org/publ/bcbsi13.htm

Davydenko, A. (2011). Determinants of bank profitability in Ukraine. Undergraduate Economic Review, 7(1), 1-30. https://digitalcommons.iwu.edu/cgi/viewcontent.cgi?article=1106\&context=uer Dogan, T. M., and Yildiz, F. (2013). The impact of the board of directors' size on the bank's performance: Evidence from Turkey. European Journal of Business and Management, 3(6), 130- 140. https://www.iiste.org/Journals/index.php/EJBM/issue/view/574

Erdogan, M., and Aksoy, E. E. (2016). Banking regulation and determinants of banks profit: Empirical evidence from Turkey. Eurasian Journal of Business and economics, 9(17), 109-124. https://www.ejbe.org/index.php /EJBE/issue/view/19

$\mathrm{Fu}, \mathrm{X}$. (M)., and Heffernan, S. (2009). The effects of reform on China's bank structure and performance. Journal of Banking \& Finance, 33(1), 39-52. https://www.sciencedirect.com/science/article/abs/pii/So378426607003755

Golubeva, O., Duljic, M., and Keminen, R. (2019). The impact of liquidity risk on bank profitability: Some empirical evidence from the European banks following the introduction of Basel III regulation. Accounting and Management Information Systems, 18(4), 455-485. https://www.diva portal.org/smash/get/diva2:1383634 /FULLTEXTo1.pdf

Hasan, M. S. A., Manurung, A. H., and Usman, B. (2020). Determinants of bank profitability with size as moderating variable. Journal of Applied Finance \& Banking, (10(1), 153-166. http://www.scienpress.com/Upload/JAFB/Vol\%2010_3_7.pdf

Heffernan, S. S., and Fu, X. Q. (2010). Determinants of financial performance in Chinese banking. Applied Financial Economics, 20(20), 1585-16oo. https://www.tandfonline.com/doi/abs/10.108o/o9603107.2010.505553

John, T. A. (2018). Effect of non-performing loans on bank performance of some selected commercial banks in the Nigerian banking sector. International Journal of New Technology and Research (IJNTR), 4(4), 11-17. https://www.ijntr.org/download_data/IJNTRo4040016.pdf

Kadioglu, E., Telceken, N., and Ocal, N. (2017). Effect of the asset quality on the bank profitability. International Journal of Economics and Finance, 9(7), 6o-68. http://www.ccsenet.org/journal/index.php/ijef/issue/view/1853

Kosmidou, K., Tanna, S., and Pasiouras, F. (2005). Determinants of profitability of domestic UK commercial banks: Panel evidence from the period 1995-2002. Economics, Finance and Accounting. Applied Research Working Paper Series, 1-27. file:///C:/Users/ACER/Downloads/RP20o8- 4\%20(1).pdf

Lartey, V. C., Antwi, S., and Boadi, E. K. (2013). The relationship between net interest margin and return on assets of listed banks in Ghana. Research Journal of Finance and Accounting, 4(16), 73-78. https://www.iiste.org/Journals/index.php/RJFA/article/viewFile/8287/8647

Lucky, L. A., and Andrew, N. A. (2015). Asset quality and profitability of commercial banks: Evidence from Nigeria. Research Journal of Finance and Accounting, 6(18), 26-34. https://core.ac.uk/download/pdf/234631038.pdf

Maryam, B. M., and Bustaman, U. S. A. (2017). CAMEL ratio on profitability banking performance (Malaysia versus Indonesia. International Journal of Management, Innovation \& Entrepreneurial Research, 3(1), 30-39. file:///C:/Users/ACER/Downloads/CAMEL_RATIO_ON_PROFITABILITY_BANKING_PERFOROMANCE M.pdf

Mehdi, E. M. (2018). Determinants of banks' profitability and performance: An overview. Munich Personal RepEc Archive (MPRA), 1-15. https://mpra.ub.uni muenchen.de/89470/1/MPRA_paper_8947o.pdf 
Merin, M. A. (2016). Determinants of bank profitability in Ethiopia: A case study of private commercial banks. Research Journal of Finance and Accounting, 7(7), 28-43. https://core.ac.uk/download/pdf/234631382.pdf

Misha, A. E. (2016). The compliance function in Banks and the need for increasing and strengthening its role lessons learned from practice. European Journal of Sustainable Development, 5(2), 171-180. http://ecsdev.org/ojs/index.php/ejsd/issue/view/21

Owiredu, A., and Kwakye, M. (2020). The effect of corporate governance on financial performance of commercial banks. International Journal of Business and Social Science, 11(5), 18-27. http://ijbssnet.com/journals/ Vol_11_No_5_May_2020/3.pdf

Rahman, M. M., Hamid, M. K., and Khan, A. M. (2015). Determinants of bank profitability: Empirical evidence from Bangladesh. International Journal of Business and Management, 10(8), 135-150. https://www.researchgate.net/publication/280554575_Determinants_of_Bank_Profitability_Empiri cal_Evidence_from_Bangladesh

Rostami, S., Rostami, Z., and Kohansala, S. (2015). The effect of corporate governance components on return on assets and stock return of companies listed in Tehran Stock Exchange. Procedia Economics and Finance, 36, 137-146. https://core.ac.uk/download/pdf/82174161.pdf

Samad, A. (2015). Determinants bank profitability: Empirical evidence from Bangladesh commercial banks. International Journal of Financial Research, 6(3), 173-179. http://www.sciedu.ca/journal/index.php/ijfr/article/view/7508/4467

Silaban, P. (2017). The effect of capital adequacy ratio, net interest margin and non-performing loan on bank profitability. International Journal of Economics and Business Administration, 5(3), 58-69. https://www.ijeba.com/dmdocuments/2017/2017_V_3_5.pdf

Sobhy, A. E., Mohamed, E. K. A., and Hussain, M. M. (2017). Corporate governance and banking performance: Experience with ten Asian countries, 1-39. file://C:/Users/ACER/Downloads/SSRN id29oo333.pdf

Sujarwo, A. A. (2015). The impact of Indonesia's bank performance towards banks' stock price (Listed in Indonesia stock Exchange from 2011 - 2013 using CAMEL analysis. iBuss Management 3(2), $9^{-} 18$. https://media.neliti.com/media/publications/183363-EN-the-impact-of-indonesias-banks performan.pdf

Sunaryo, D. (2020). The effect of capital adequacy ratio (CAR), net interest margin (NIM), non-performing loan (NPL), and loan to deposit ratio (LDR) again return on asset (ROA) in general banks in Southeast Asia 20122018. Ilomata International Journal of Management, 1(4), 149-158. https://www.ilomata.org/index.php /ijjm/article/view/110/92

Supriyono, R. A., and Herdhayinta, H. (2019). Determinants of bank profitability: The case of the regional development bank (BPD Bank) in Indonesia. Journal of Indonesia Economy and Business, 34(1), 1-17. https://jurnal.ugm.ac.id/jieb/article/view/17331 